\title{
Study on the Risk Identification Model and Countermeasures of Cruise under Epidemic Situation
}

\author{
Shengjun Gan, Jie Xu \\ School of Economics and Management, Shanghai Maritime University, Shanghai, China \\ Email: gsseminar@126.com
}

How to cite this paper: Gan, S. J., \& Xu, J. (2020). Study on the Risk Identification Model and Countermeasures of Cruise under Epidemic Situation. Journal of Service Science and Management, 13, 824-840. https://doi.org/10.4236/jssm.2020.136051

Received: November 4, 2020

Accepted: December 27, 2020

Published: December 30, 2020

Copyright $\odot 2020$ by author(s) and Scientific Research Publishing Inc. This work is licensed under the Creative Commons Attribution International License (CC BY 4.0).

http://creativecommons.org/licenses/by/4.0/

\begin{abstract}
In order to provide a scientific basis for the government to manage the risk aversion of large-scale public health events of cruise ships and coordinate the handling of the crisis brought by cruise ship docking under the epidemic situation, a set of process model of cruise epidemic prevention risk identification is identified and reflected. Based on the cruise risk identification model, the risk factors, early warning risk level and early warning measures are scored to get the final cruise epidemic risk value, trigger the corresponding level of cruise epidemic multi-level emergency response system and take measures. Based on the experience of cruise risk cases at home and abroad, the risk identification process model is established to find the breakthrough of risk control, which lays the foundation for the cruise industry to establish a complete system of international cruise epidemic prevention and control system.
\end{abstract}

\section{Keywords}

Cruise, Risk Identification, Epidemic Prevention and Control

\section{Introduction}

A novel coronavirus outbreak during the Spring Festival in 2020 has undoubtedly given the cruise industry a difficult problem. When cruise companies implement the policy of free refund, the direct economic losses are embodied in the port berthing fees, crew labor costs, reserved food and entertainment service expenses and ticket sales expenses of relevant routes. In the long run, in terms of market capacity, due to the uncertainty of the lifting time of the epidemic ban, conditional cruise companies may rearrange their cruise routes in order to reduce their losses. This adjustment in transport capacity will break the balance of 
supply and demand in other cruise markets, and further intensify market competition. In terms of market sentiment, the worries of cruise passengers are not completely eliminated, and passengers need to pay more time to restore confidence in cruise travel.

The epidemic has brought serious negative effects to tourism, hotel industry, financial industry and other industries. Since the establishment of public health emergency mechanism according to international health regulations in 2005, six public health emergencies of international concern announced by the World Health Organization, such as SARS, H1N1 influenza, Ebola virus, mers, etc., have more or less affected the cruise industry. Therefore, the novel coronavirus pneumonia outbreak in 2020 is not the first time that the cruise industry is facing the epidemic problem (Han et al., 2018). Since the outbreak of the epidemic, cruise ships have become a "virus walking on the sea". Although there are no confirmed or suspected cases of some cruise ships, the number of ports refusing to stop cruise ships is increasing.

The cruise industry has accelerated the spread of the virus due to its characteristics of high population density, closed space and many parking places. The novel coronavirus pneumonia epidemic has three special characteristics in the cruise industry: group, chain and difficulty to identify. The space of cruise ships is relatively dense, with large passenger capacity and high personnel density. Most cruises take more than five days and gather for a long time. The internal environment of cruise ships is relatively narrow, and food and living are relatively concentrated. There are many places for cruise ships to stop, and it is difficult to distinguish the specific symptoms of coronavirus and other viruses. The characteristics of cruise tourism accelerate the spread of the epidemic ( $\mathrm{Lu}$ et al., 2013).

\section{Typical Cases}

Recently, the cruise safety problem under the new coronavirus epidemic has spread to the policy level. During the epidemic period, cruise ships such as "Diamond Princess", “ "ms Westerdam” and "Costa Serena" were all facing the risk of being infected by the virus. However, due to the different home port and the prevention and control measures taken by the ship's personnel, the fate of cruise ships is very different. The last group of 145 crew members and passengers disembarked from the ship on March 15, and the test results were negative. Since February 5, when there were confirmed patients, a total of 712 people on the cruise ship confirmed infection. "Diamond Princess" carried $1045 \mathrm{crew}$ and staff, 2666 passengers, a total of 3711 people, the number of infected people accounted for nearly one fifth of the total number of the ship. "Costa Serena", which is quite different from the diamond princess, has been praised by the media and the public for its correct handling method and positive attitude towards public health emergencies (Song, 2020). Go forward with great strength and vigour novel coronavirus, which was held in Tianjin from January 20, 2020, with 3706 tourists and 1100 crew members. The original journey of the relaxed jour- 
ney was interrupted by the outbreak of a new coronavirus in Wuhan. There were more than 140 passengers from Hubei. After receiving the emergency notice, the Tianjin epidemic prevention and control headquarters immediately responded to the emergency notice and issued instructions as soon as possible. In the early morning of the 25th, disease experts and medical workers were organized to board the ship for testing. Within 24 hours, a series of work including medical inspection, sample collection, temperature measurement and virus detection was completed. At the same time, all tourists were organized to disembark. The International Cruise Association (CLIA) has issued the strictest travel ban since February 3, suspending cruise travel in China, South Korea, Iran and northern Italy. Generally speaking, the cruise market is greatly affected by the epidemic situation, and its anti risk ability is weak, and it is in the adjustment period. Most cruise companies are facing difficulties in operation, but the scale of cruise market is relatively small compared with other transportation fields.

In response to the "Diamond Princess" incident, the public has been arguing about the responsibility of the cruise home port. Some scholars believe that Japan's rescue of the Diamond Princess belongs to "humanitarian" assistance (Peng et al., 2020). If the coastal countries think that the cruise ship epidemic poses a threat to its safety, it cannot allow it to dock. Another group of scholars believes that the home port of call has the obligation to accept and assist in epidemic prevention and control, and should not refuse to enter the port. In this paper, we do not pay more attention to the legal and moral issues of cruise ships, focusing on the lessons learned and lessons learned from this major cruise public health event. Cruise home port is the main business place of cruise, and the problem of cruise berthing belongs to the responsibility of the home port. It is the focus and difficulty of this paper to coordinate and deal with the crisis caused by Cruise berthing under the epidemic situation.

\section{Risk Identification Model}

\subsection{Risk Identification Process}

Cruise risk identification factors are divided into biological factors, attitude factors, natural factors and social factors. There are many sub factors under these four main factors, which constitute the cruise ship epidemic prevention risk identification process (Figure 1).

\subsubsection{Biological Factors}

The novel coronavirus disease (COVID-19) is a contagious disease caused by SARS CoV-2 virus, which is mainly manifested as acute respiratory disease, accompanied by interstitial and alveolar pneumonia, which can involve multiple organs such as kidney, heart, digestive tract, blood and nervous (Naicker et al., 2020) system. Seven novel coronavirus species are found, and new coronavirus and SARS virus can cause more serious human diseases. There are three ways of virus transmission: droplet transmission, contact transmission and air transmission. According to the novel coronavirus clinical study, pathogens can 
Risk identification process of cruise ship epidemic prevention

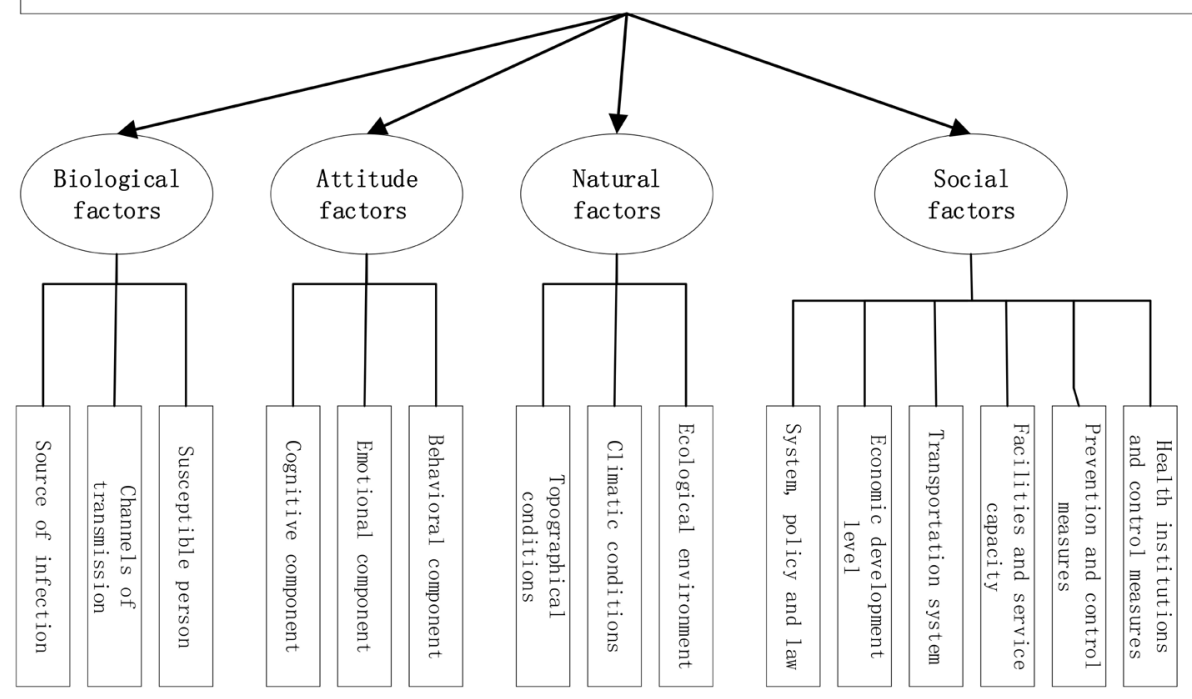

Figure 1. Process chart of cruise ship epidemic prevention risk identification.

also be transmitted through the digestive tract. At present, the novel coronavirus is not identified at the source, and bat that has been used as a source can only infect human beings as intermediate hosts. Further research and demonstration are needed for the source of infection. In this novel coronavirus pneumonia epidemic, many severe patients are middle-aged and elderly. In particular, novel coronavirus is more likely to infect people with a history of illness. Because of the serious organ failure of the elderly, they are easy to be infected, and even cause death once infected. Compared with the elderly, children are also vulnerable groups. Children's resistance is poor, need adult care, easy to contact with objects with virus. Cruise, as a place of leisure and entertainment, has been regarded as the preferred place for family holiday tourism in recent years. The elderly and children account for a certain proportion in the number of cruise tourists. Because of its relatively closed space and large population density, cruise ship increases the possibility of virus transmission unconsciously. The clinical and epidemiological characteristics of infectious diseases, as well as the transmissibility and pathogenicity of the virus were comprehensively considered (Wang et al., 2011). The risk identification of cruise biological factors should be carried out from three sub factors of infection source, transmission route and susceptible population.

\subsubsection{Attitude Factors}

Attitude is an evaluative statement of an object, person or event, which is composed of three components: cognition, emotion and behavior. Cognition refers to the viewpoint, knowledge and belief possessed by individuals. Emotion is the feeling part of attitude, which leads to behavioral results. Behavior refers to an individual's intention to act on someone or something. Patients infected with novel coronavirus pneumonia are experiencing physical and psychological tor- 
ture, and also bring fear and anxiety to their families. The novel coronavirus is not understood by many tourists, and is prone to cause mental illness such as hypochondria, depression, sleep disorders, and so on. The understanding and cognition of the disease will help tourists to maintain their psychological stability, maintain a positive and optimistic attitude towards the arrival of the epidemic situation, and provide psychological counseling for other tourists on the cruise ship who do not know the epidemic situation, so as to avoid the occurrence of excessive reactions such as panic and riot in behavior, and try to avoid the emergence of population vulnerability characteristics (Xue \& Yao, 2014). The risk identification of cruise attitude factors should be carried out from three sub factors of cognition, emotion and behavior.

\subsubsection{Natural Factors}

The geological disasters mainly caused by earthquake will damage the shore wall of the cruise home port, which makes the foundation lose the bearing capacity under strong earthquake, and lead to the collapse of port buildings. When the cruise ships enter and leave the home port, they are easily affected by extreme weather such as fog and typhoon. In such bad weather, it is difficult for cruise ships to dock at the home port, which will lead to mass incidents such as tourists' detention. In addition, the cruise economy also has a negative impact on the ecological environment. A large number of garbage and sewage produced by cruise ships are harmful to the water quality of the sea area. These are easy to lead to fire, explosion, flammable and explosive toxic gas leakage and other safety accidents in cruise terminal. Risk identification of cruise natural factors should be carried out from three sub factors: geological factors, meteorological factors and ecological environment.

\subsubsection{Social Factors}

Cruise economy is committed to developing cruise industry chain and promoting economic growth. The national system and the economic development level of the home port area play a decisive role in the development of the local cruise industry. Cruise policy provides a good environment for the development of local postal industry, and the accessible transportation is an integral part of the core competitiveness of cruise home port. Cruise facilities and service capacity determine the service level of cruise. The contents of cruise ship quarantine and supervision are comprehensive, which requires the quarantine personnel to have a comprehensive understanding of the ship's internal environment. The cruise ship's prevention and control measures involve many work contents and heavy workload, so as to keep close contact with local health institutions to ensure that the local government and various health departments can be informed of the epidemic situation in time. The risk identification of cruise social factors should be carried out from the sub aspects of system, policy and law, economic development level, transportation system, facilities and service capacity, prevention and control measures, health institutions and control measures. 
There are some logical relationships among the four main factors in the process of cruise risk identification. (Figure 2) novel coronavirus has a huge impact on the physical and psychological condition of passengers. Virus can harm human body and health, and has a negative impact on various industries. For the recognition of natural disasters and viruses, passengers can calm down in the face of emergencies, and actively cooperate with cruise staff and local health authorities for isolation and detection. The superior system and loose policies enable the staff of cruise ships to adopt early warning scheme in the face of natural disasters and virus invasion, so as to deal with emergencies quickly in the first time, ensure the safety of personnel and protect the interests of cruise ships to the greatest extent. To sum up, except that there is no direct logical relationship between natural factors and biological factors, the other two factors are interactive.

\subsection{Risk Identification Model}

In order to change the risk identification index into objective quantitative calculation value and convert the qualitative index into quantitative index, so as to make the risk identification model more standardized and comprehensive, this paper considers that the risk identification model includes three research indicators: risk factor score, early warning risk level and early warning measures (Yang et al., 2010).

Risk value $=$ risk factor score $\times$ early warning risk grade score - early warning Measure score.

\subsubsection{Risk Factor Score}

Risk factor assessment is a complex process, which needs to overcome subjectivity and one sidedness, and embody science and standard (Wang et al., 2017). Invite cruise industry experts, port directors, local health departments and tourism departments to score the risk identification factors. According to the analytic hierarchy process (AHP), the risk identification and assessment of cruise epidemic situation are set as the target level, the main risk identification factors are taken as the criteria layer, and the sub factors of each layer are used as the index layer to calculate the final risk factor score results (Guo \& Xu, 2019) (Table 1).

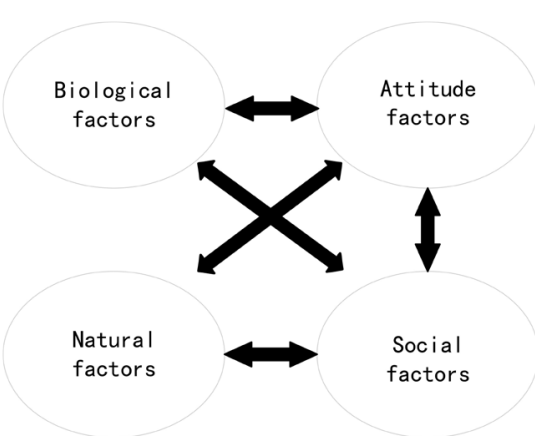

Figure 2. Logic diagram of risk identification factors. 
Table 1. Hierarchical structure model of cruise ship epidemic risk factors.

\begin{tabular}{|c|c|c|}
\hline A target layer & B criterion layer: main factor & $\mathrm{C}$ index layer: sub factors \\
\hline \multirow{16}{*}{$\begin{array}{l}\text { A Risk factors } \\
\text { assessment of } \\
\text { a cruise ship } \\
\text { epidemic }\end{array}$} & & $C_{1}$ source of infection \\
\hline & $\mathrm{B}_{1}$ biological factors & $\mathrm{C}_{2}$ transmission route \\
\hline & & $\mathrm{C}_{3}$ susceptible population \\
\hline & & $\mathrm{C}_{4}$ cognitive component \\
\hline & $\mathrm{B}_{2}$ attitude factors & $\mathrm{C}_{5}$ emotional components \\
\hline & & $\mathrm{C}_{6}$ behavioral components \\
\hline & & $\mathrm{C}_{7}$ geological factors \\
\hline & $\mathrm{B}_{3}$ natural factors & $\mathrm{C}_{8}$ meteorological factors \\
\hline & & $\mathrm{C}_{9}$ ecological environment \\
\hline & & $\mathrm{C}_{10}$ system, policy and law \\
\hline & & $\mathrm{C}_{11}$ economic development level \\
\hline & & $\mathrm{C}_{12}$ transportation system \\
\hline & $\mathrm{B}_{4}$ social factors & \\
\hline & & $\mathrm{C}_{13}$ facilities and service capacity \\
\hline & & $\mathrm{C}_{14}$ prevention and control measures \\
\hline & & $\mathrm{C}_{15}$ health institutions and control measures \\
\hline
\end{tabular}

\subsubsection{Early Warning Risk Rating}

The early warning risk level is divided into five levels, and the cruise warning level table is formulated according to the possible events at different levels (Table 2). According to the early warning level table of cruise ship accidents, the level of each cruise risk event is judged. The risk events include infectious diseases, port operation obstruction, mass malignant events caused by panic and extreme weather on the sea, and the accident risk value is calculated (Table 3).

The total risk value of the accidents that have not been rectified up to the current time point is calculated as follows:

$$
Y_{1}=A_{1} * a_{1}+A_{2} * a_{2}+A_{3} * a_{3}+A_{4} * a_{4}+A_{5} * a_{5}
$$

where $Y_{1}$-total risk value of accident;

$A_{1}$ - The number of level 1 red accidents;

$A_{2}$ - The number of level 2 orange accidents;

$A_{3}$ - The number of level 3 yellow accidents;

$A_{4}$-The number of level 4 Blue accidents;

$A_{5}$ - The number of level 5 general accidents;

$a_{1}$-Level 1 red accident risk assignment;

$a_{2}$ - Level 2 orange accident risk assignment;

$a_{3}$-Level 3 yellow accident risk assignment;

$a_{4}$-Level 4 Blue accident risk assignment;

$a_{5}$-Level 5 general accident risk assignment; 
Table 2. Cruise ship accident warning level.

\begin{tabular}{llll}
\hline Grade Risk level $\begin{array}{l}\text { Color } \\
\text { representation }\end{array}$ & $\begin{array}{l}\text { Defensive } \\
\text { state }\end{array}$ & $\begin{array}{l}\text { Degree of } \\
\text { influence }\end{array}$
\end{tabular} Types of events that are more likely to occur

The occurrence of class A or class B infectious diseases under class a

management; port paralysis, especially serious damage to port traffic capacity, or serious disorder of port order and significant impact, and grounding of important navigation channels. The number of participants is more than 1000 , and mass Especially vicious events such as beating, smashing and robbing occur, causing more than

Level 1 high red Isolation alert serious 30 people injured and causing more than 1 million direct property losses. It is impact predicted that in the next 24 hours, the wind force of force 12 or above (or the gust of force 13 or above) may occur and may continue; the rainfall will reach or have reached more than $100 \mathrm{~mm}$ within 3 hours, and the rainfall may continue; the weather is extremely hot, and the maximum temperature within 24 hours will reach more than 39 ; and strong dense fog with visibility less than 50 meters may appear or have occurred within 2 hours, and may continue.

Especially serious class B or class C infectious diseases occur; local paralysis of the port, especially serious damage to port traffic capacity, or serious disorder and impact of port order, and serious blockage of important navigation channels. The number of participants is more than 300 and less than 1000, and mass malignant events, such as crowding and trampling, cause injuries to more than 10 people Level 2 higher orange Danger alert $\begin{aligned} & \text { Serious } \\ & \text { impact }\end{aligned}$ and less than 30 people, and cause more than 500,000 direct property losses. Tropical cyclones may or have been affected by tropical cyclones within 12 hours. It is predicted that winds of force 11 or above (or gusts of force 13 or above) may occur and may continue in the next 24 hours; the rainfall will reach or have reached more than $50 \mathrm{~mm}$ within 3 hours, and the rainfall may continue; the weather is extremely hot, and the maximum temperature within 24 hours will reach more than 37; and the visibility may or has been less than 200 meters in 6 hours, more than 50 meters thick fog, and may continue.

General class B or serious class C infectious diseases occur; the port is blocked, the port capacity is seriously damaged, and the important waterway is seriously blocked. The number of participants is more than 30 and less than 300 , and mass vicious events such as fighting, fighting and rioting occur, causing injuries to more than 3 people and less than 10 people, and causing direct property losses of more than 100,000. Tropical cyclones may or have been affected by tropical Level 3 commonlyyellow

Emergency Heavy alert impact cyclones in 24 hours. It is predicted that winds of magnitude $9-10$ or above (or gusts of force $11-12$ or above) may occur in the sea area in the next 24 hours and may continue; the rainfall will reach or have reached more than $50 \mathrm{~mm}$ within 6 hours, and the rainfall may continue; the weather is extremely hot, and the maximum temperature within 24 hours will reach 35 degrees or close to 35 degrees; it may or may have occurred within 12 hours Strong fog with visibility less than $500 \mathrm{~m}$ and greater than $200 \mathrm{~m}$ may last.

Mild class B or general class C infectious diseases occur; port congestion, port throughput capacity is damaged, and important navigation channels are blocked. The number of participants is more than 5 and less than 30 , and a group of malignant events such as rioting occurred, causing small-scale personnel injury

Level 4 Lower blue Watch out $\begin{aligned} & \begin{array}{l}\text { Slight } \\ \text { impact }\end{array}\end{aligned}$ and causing more than 30,000 direct property losses. It is predicted that the sea area may or has been affected by mild tropical cyclones within 24 hours. It is predicted that the sea area will have wind force of magnitude 7 - 8 or above (or gusts of force $9-10$ or above) and may continue in the next 24 hours; the rainfall will reach or have reached more than $50 \mathrm{~mm}$ within 12 hours, and the rainfall may continue.

Mild class C infectious diseases occurred; the port was unblocked, the port traffic Level 5 low green $\quad \begin{array}{ll}\text { Normal } \\ \text { operation }\end{array} \quad \begin{aligned} & \text { Basically } \\ & \text { no effect }\end{aligned}$ capacity was good, and there was basically no channel blockage. There is no serious group event, no personal injury or property loss, no extreme weather impact, and the cruise ship is running normally at sea, with high visibility and little or no precipitation. 
Table 3. Accident classification and quantitative assignment of accident risk.

\begin{tabular}{cc}
\hline Grade & Corresponding score $\left(a_{n}\right)$ \\
\hline Level 1 red accident & 2.0 \\
Level 2 orange accident & 1.5 \\
Level 3 yellow accident & 1.0 \\
Level 4 blue accident & 0.5 \\
Level 5 general accident & 0.1 \\
\hline
\end{tabular}

\subsubsection{Score of Early Warning Measures}

The score of early warning measures has a negative effect on the risk value of cruise epidemic. The efforts of all parties in the cruise industry chain to improve the early warning measures can greatly reduce the risk score value. The calculation formula of quantitative value of early warning Measure score is as follows

$$
Y_{2}=Y_{1} * M_{1} * N_{1}+Y_{1} * M_{2} * N_{2}+Y_{1} * M_{3} * N_{3}+\cdots Y_{1} * M_{n} * N_{n}
$$

where $Y_{2}$-quantitative value of early warning measures;

$Y_{1}$-Total risk value of accident;

$M_{n}$-The measure multiplier is $20 \%$ at the government level, $10 \%$ at the company level, $5 \%$ at the department level and $1 \%$ at the team level;

$N_{n}$-The corresponding quantity of measures should be implemented.

\section{Countermeasures against Cruise Epidemic}

The multi-level emergency response system of cruise ship epidemic situation is a comprehensive treatment system of epidemic situation implemented by different emergency subjects according to different warning levels and risk scoring system. According to the principle of "unified command and clear division of labor", the system mobilizes corresponding personnel and resources in strict accordance with the different levels of emergencies, and carries out different degrees of treatment to prevent the waste of resources. The multi-level emergency response system of cruise epidemic situation is divided into two main bodies, one is the cruise port under the leadership of the government, the other is a profit-making organization mainly composed of cruise companies and travel agencies. For different management bodies, after risk assessment and scoring, different measures should be taken to face the cruise epidemic situation, so that each department performs its own duties and has a clear division of labor. When the event is handled, information tracking and feedback should be timely carried out as the source of early warning data. At the same time, the multi-level emergency response system of cruise ship epidemic situation is divided into long-term and short-term, the short-term system is used as the emergency response system, and the long-term system is used as the response measure system to guide the short-term emergency, so as to achieve the unity of integrity and thoroughness in time and processing strength (Figure 3). 


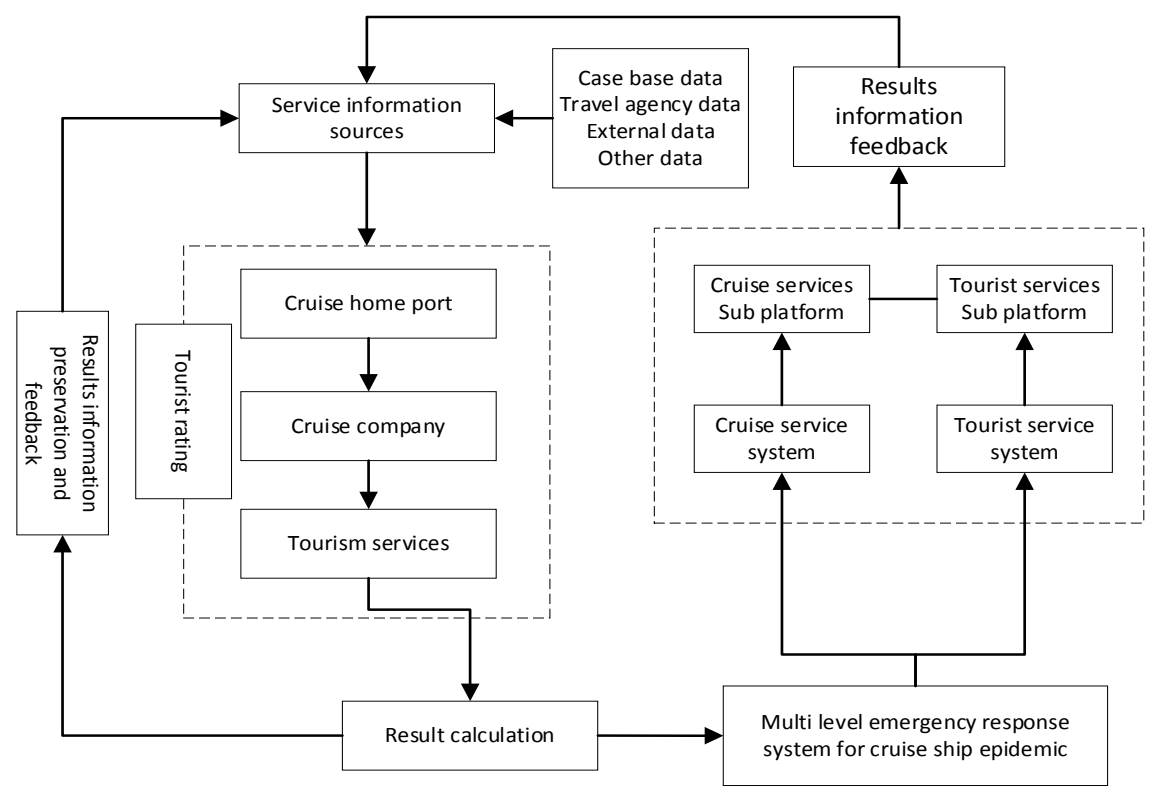

Figure 3. Flow chart of cruise epidemic risk identification model.

\subsection{Short Term Emergency Measures}

The implementation subject of short-term emergency measures is divided into profit-making organizations composed of cruise ports, cruise companies and travel agencies under the leadership of the government. In case of cruise ship epidemic emergency, the main emergency measures are as follows: (Table 4, Table 5).

\subsection{Long Term Emergency Measures}

The implementation subject of short-term emergency measures is divided into profit-making organizations composed of cruise ports, cruise companies and travel agencies under the leadership of the government. In case of cruise ship epidemic emergency, the main emergency measures are as follows:

\subsubsection{Government and Port}

First, accelerate the construction of China's cruise big data platform. Establish a database of epidemiological investigation on cruise ships, upload various cases of epidemics on cruise ships, so that the staff and passengers on board can fully understand the characteristics and transmission ways of various epidemic infectious diseases, exchange data inside and outside the cruise ship through the information network, and update the knowledge system in real time (Xue, 2018).

Second, pay attention to people's safety interests and emergency management. In the design, construction and operation of cruise ships, more attention should be paid to safety factors, and the construction of cruise emergency hardware facilities should be increased, especially the construction of patient isolation area, quarantine area and cruise emergency special channel, so as to achieve "zero contact" and "zero infection". Immediately arrange other travel itineraries for 
passengers free of infectious diseases, and achieve "zero waiting time" clearance (Wang et al., 2010).

Table 4. Short term emergency measures for epidemic emergencies in Cruise Port.

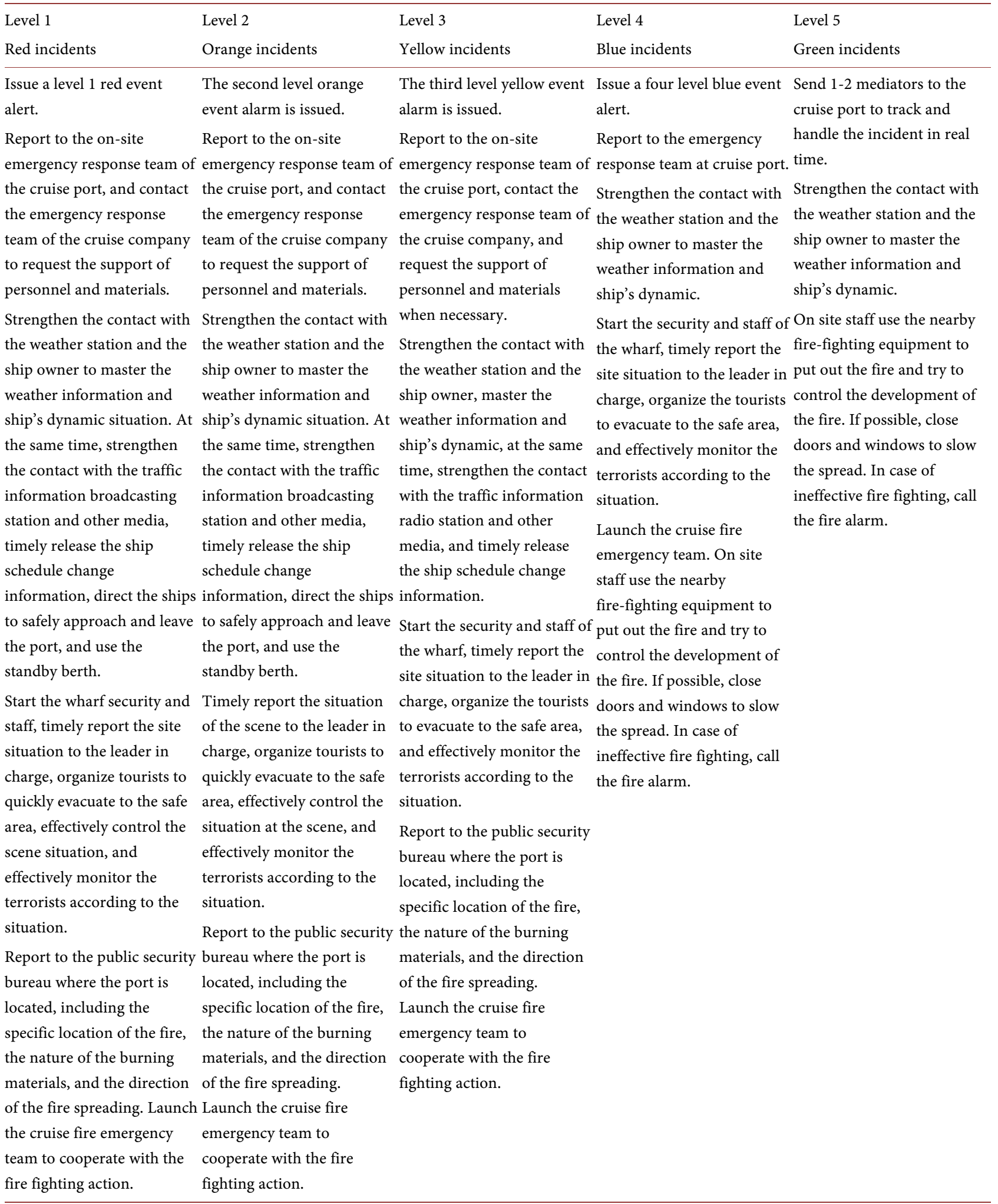


Table 5. Short term emergency measures for cruise companies.

\begin{tabular}{|c|c|c|c|c|}
\hline Level 1 red incidents & Level 2 Orange incidents & Level 3 yellow incidents & Level 4 Blue incidents & Level 5 Green incidents \\
\hline Organize passengers to & Organize passengers to & Organize passengers to & Organize passengers to & Organize passengers to \\
\hline strengthen service and order & r strengthen service and order & strengthen service and order & strengthen service and order & strengthen service and order \\
\hline maintenance, and use & maintenance, and use & maintenance, and use & maintenance, and use & maintenance. Strengthen \\
\hline standby waiting room. & standby waiting room. & standby waiting room. & standby waiting room. & radio publicity to stabilize \\
\hline Strengthen radio publicity & Strengthen radio publicity & Strengthen radio publicity & Strengthen radio publicity & passengers' mood. The \\
\hline to stabilize passengers' & to stabilize passengers' & to stabilize passengers' & to stabilize passengers' & leader in charge will report \\
\hline mood. Do a good job in & mood. Strengthen passenger & mood. Strengthen passenger & mood. The leader in charge & the relevant situation to the \\
\hline passenger service of square, & transport services in & transport services in & will report the relevant & port in the region. \\
\hline wharf and standby waiting & squares, docks and standby & squares, docks and standby & situation to the port in the & Organize passengers to \\
\hline room. Strengthen passenger & waiting rooms. The leader & waiting rooms. The leader & region. & strengthen service and order \\
\hline transport services in & in charge will report the & in charge will report the & Organize passengers to & maintenance, and cooperate \\
\hline squares, docks and standby & relevant situation to the & relevant situation to the port & strengthen service and order & with cruise companies. \\
\hline waiting rooms. The leader & local port and government. & in the region. & maintenance, and cooperate & $o$ a good job in square and \\
\hline in charge will report the & Organize passengers to & Organize passengers to & with cruise companies. & wharf service. Strengthen the \\
\hline $\begin{array}{l}\text { relevant situation to the } \\
\text { local port and government. }\end{array}$ & $\begin{array}{l}\text { strengthen service and order } \\
\text { maintenance, cooperate }\end{array}$ & $\begin{array}{l}\text { strengthen service and order } \\
\text { maintenance, cooperate }\end{array}$ & Do a good job in square and & contact with cruise staff and \\
\hline Organize passengers to & with cruise companies and & with cruise companies and & $\begin{array}{l}\text { wharf service. Strengthen } \\
\text { the contact with cruise staff }\end{array}$ & $\begin{array}{l}\text { tour leaders to master the } \\
\text { dynamic information of }\end{array}$ \\
\hline strengthen service and order & r travel agencies to actively & travel agencies to actively & and tour leaders, master the & group events. \\
\hline maintenance, cooperate & organize "non forced & organize "non forced & dynamic information of & \\
\hline with cruise companies and & detention" cruise tourists to & detention" cruise tourists to & group events, and at the & \\
\hline travel agencies to actively & get off the ship quickly, & get off the ship quickly, & same time, strengthen the & \\
\hline organize "non forced & safely and orderly. & safely and orderly. & contact with traffic radio & \\
\hline detention" cruise tourists to & Do a good job of necessary & Do a good job of necessary & and other media, and timely & \\
\hline get off the ship quickly, & services, and actively assist & services, and actively assist & release ship schedule change & \\
\hline safely and orderly. & the "stranded" tourists who & the "stranded" tourists who & information. & \\
\hline Do a good job of necessary & are willing to leave the ship & are willing to leave the ship & & \\
\hline services, and actively assist & after persuasion. Do a good & after persuasion. Do a good & & \\
\hline the "stranded" tourists who & job in square and wharf & job in square and wharf & & \\
\hline are willing to leave the ship & service. Strengthen the & service. Strengthen the & & \\
\hline after persuasion. Do a good & contact with cruise staff and & contact with cruise staff and & & \\
\hline job in square and wharf & tour leaders, master the & tour leaders, master the & & \\
\hline service. & dynamic information of & dynamic information of & & \\
\hline Strengthen the contact with & group events, and at the & group events, and at the & & \\
\hline cruise staff and tour leaders, & same time, strengthen the & same time, strengthen the & & \\
\hline master the dynamic & contact with traffic radio & contact with traffic radio & & \\
\hline information of group & and other media, and timely & and other media, and timely & & \\
\hline events, and at the same & release ship schedule change & release ship schedule change & & \\
\hline time, strengthen the contact & information. & information. & & \\
\hline with traffic radio and other & & & & \\
\hline media, and timely release & & & & \\
\hline ship schedule change & & & & \\
\hline information. & & & & \\
\hline
\end{tabular}

Third, full consideration should be given to the interests of cruise companies. We should adopt the policy of reducing port charges by stages, reducing the port use fees and capitation fees for international cruise ships as appropriate, including port enterprises into tax preference objects, increasing subsidies and support for local cruise parent companies and travel agencies, strengthening contact with cruise companies and discussing countermeasures, and giving full play to the government's coordinating role to help enterprises tide over difficulties.

Fourth, establish information reporting system. All kinds of effective information on the cruise ship should be uploaded to the cruise information reporting 
system in time. The information system should send special information staff to achieve 24-hour regular report and 6-hour timely update. In case of major emergency, it should be immediately uploaded to the emergency information area, and the local government and Health Department of the cruise ship should be informed in the first time, and the emergency response team on the cruise ship should be informed to formulate emergency response Plan and take emergency measures. According to the order of first cruise home port and then port of call, information exchange and sharing are carried out for each port on the cruise line. To establish an information network, the information contact person of each port should contact with other port contacts in the first time, and strictly report the various situations of the cruise ships to be docked, so as to ensure that the responsibility is implemented at each stop of the cruise ship (Xia et al., 2019).

Fifth, play a unified and coordinated role. Set up a "cruise market working group" to coordinate the local tourism bureau, health department, Port Bureau, joint inspection units, travel agencies and cruise companies to strengthen communication and cooperation, regularly collect cruise operation and emergency conditions, and summarize the work content. In case of major public health events, the "three points of unification" of the government, local departments and cruise ships can be achieved at the first time In order to speed up the treatment of large-scale epidemic, we should start a unified emergency plan and take various measures of home port and local government to control.

Sixth, strengthen port quarantine. Careful preparations should be made before boarding. Select the personnel with quarantine work experience, formulate the quarantine scheme, and keep close contact with the cruise ship principal or his agent to ensure that the quarantine personnel can work efficiently. The quarantine personnel should know the internal climate and environment, public health status, food status, medical supplies, waste and other issues in advance to effectively carry out inspection and quarantine (Yu et al., 2013) work. According to the international cruise health and quarantine standards, fully understand the importance of scientific assessment and scientific quarantine, regularly train cruise staff (Bi et al., 2008), conduct online and offline tests for cruise staff, and conduct regular emergency drills for public health emergencies in cruise port. Set up a cruise port major incident emergency team, and conduct high-intensity emergency special training for the team members.

Seventh, the health status of passengers and staff is regularly reported to the cruise health system by using the cruise health QR code, and the health status of the staff and passengers on the cruise ship can be tracked in real time by using the health QR code as the certificate for entering and leaving each activity area and home port of the cruise. The cruise health system is monitored and fed back by the members of the cruise port emergency team. Once the early warning system is triggered, emergency measures will be taken immediately for rescue.

\subsubsection{Cruise Companies and Travel Agencies}

First, rekindle the consumption enthusiasm of cruise consumers. Cruise compa- 
nies will better reflect the safety factors in the construction and design of cruise ships, accelerate the completion of short board, quickly re launch new business, actively launch and expand safe cruise tourism product line, design more diversified tourism and leisure products, and give certain tourism subsidies. After the end of the epidemic, international cruise lines can be developed at home and at sea without destination. The company should be prepared to maintain a low level of revenue and try its best to recover losses.

Second, adjust the cruise industry chain in the middle and lower reaches. Enterprises should formulate industrial chain adjustment plan to cope with the sudden decrease in the number of tourists and the huge impact on business caused by the epidemic. Timely release the change policy and voyage cancellation to passengers, and issue the Refund Scheme of voyage suspension. We should do a good job of linking up with suppliers, carry out annual stock preparation, and fully cooperate with suppliers and labor agents affected by the epidemic situation, so as to jointly meet the comprehensive rejuvenation of the cruise industry.

Third, do a good job in epidemic prevention propaganda. Combined with psychological propaganda, let passengers fully realize the seriousness and curability of the disease. Explain public health and safety knowledge for passengers to eliminate consumers' concerns. Establish a wechat group for passengers and staff during the trip, use wechat group to release safety knowledge in time, set up health column TV programs on cruise ships, and timely broadcast policies and measures, epidemic prevention knowledge, work trends, etc. through multiple online media platforms. Increase media publicity, and conduct real-time reports on cruise companies' outstanding performance in epidemic prevention and control, so as to give the cruise market and the public confidence to overcome the epidemic.

Fourth, personnel training and talent reserve. According to the international cruise health and quarantine standards, regular training for cruise staff, online and offline testing for cruise staff, and regular emergency drills for public health emergencies. Set up a cruise company's emergency response team for major incidents, and conduct high-intensity emergency special training for the team members. During the epidemic period, personnel recruitment efforts will be strengthened, and double staff wages and subsidies will be given; after the epidemic, the staff who have participated in the anti epidemic work will be rewarded as emergency reserve talents of cruise companies.

Fifthly, establish emergency supply channels. The home port of cruise ship should reserve appropriate amount of food and drinking water to ensure that daily necessities can be delivered in time in case of long-term natural disasters, so as to meet the basic needs of passengers and staff on the cruise ship berthing in emergency.

\section{Conclusion}

The development of cruise industry is conducive to the formation of an indus- 
trial chain, the expansion of employment, the promotion of local economic development, and at the same time, it meets the people's needs for diversified life. The cruise market is greatly affected by the epidemic situation. According to the characteristics of cruise ships and the urgency and particularity of epidemic prevention and control, the government should effectively identify various risk factors, coordinate and deal with the cruise berthing crisis under the epidemic situation, and formulate scientific, effective and targeted prevention and control programs and measures, so as to increase the impetus for the revival of the cruise market.

The innovation of this paper is to identify and reflect a set of cruise ship epidemic prevention risk identification process model. Based on the cruise risk identification model, the risk factors, early warning risk level and early warning measures are scored to get the final cruise epidemic risk value, trigger the corresponding level of cruise epidemic multi-level emergency response system and take measures. The disadvantage is that the model needs to be put into the simulation experiment to get accurate and effective data.

\section{Conflicts of Interest}

The authors declare no conflicts of interest regarding the publication of this paper.

\section{References}

Bi, Y. G., Qi, J., Zhou, J. Y., Liu, Y. K., Guo, J. J., Meng, D. P., Chi, C., Wang, F. X., Yang, P. C., Tan, X. L., \& Hou, Y. S. (2008). Discussion on Emergency Disposal of Infected Ships. Chinese Journal of Frontier Health and Quarantine, 31, 371-374+381. https://kns.cnki.net/kcms/detail/detail.aspx?dbcode=CJFD\&dbname=CJFD2008\&filen ame=GJWJ200806005\&v=MjE4OTBabUZ5M2hWcnpOSWlmY1pMRzRIdG5NcVk5Rl 1ZUjhlWDFMdXhZUzdEaDFUM3FUcldNMUZyQ1VSN3FlWmU=

Guo, Z. R., \& Xu, B. (2019). Construction of Avian Influenza Risk Assessment Model in Yangzhou City. Henan Agriculture, No. 32, 47-48+50. https://kns.cnki.net/kcms/detail/detail.aspx?dbcode=CJFD\&dbname=CJFDLAST2019 \&filename $=$ NYHN201932026\&v=MDc4NzdvUjhlWDFMdXhZUzdEaDFUM3FUcldN MUZyQ1VSN3FlWmVabUZ5M2hVTDNBS3pURFlMRzRIOWpQclk5SFk=

Han, H. et al. (2018). Thinking on Risk Assessment of Infectious Diseases at Ports. Port Health Control, 23, 8-10, 13. https://kns.cnki.net/kcms/detail/detail.aspx?dbcode=CJFD\&dbname=CJFDLAST2018 \&filename $=$ KAWS201801003\&v=MTMwNTMzcVRyV00xRnJDVVI3cWVaZVptRnkz Z1dydktMaXpjZmJHNEg5bk1ybzlGWjRSOGVYMUx1eFlTN0RoMVQ=

Lu, Z. S., Li, P., Tian, Z. G., Shi, F., Wang, G. J., Wang, L., Kong, C. Z., Zhang, Y. H., Jiang, Y. F., \& Zhang, Q. (2013). Risk Identification and Assessment Report of International Cruise Infectious Diseases. Chinese Journal of Frontier Health and Quarantine, $36,60-64$.

https://kns.cnki.net/kcms/detail/detail.aspx?dbcode=CJFD\&dbname=CJFD2013\&filen ame=GJWJ201301018\&v=MTg0NDR1eFlTN0RoMVQzcVRyV00xRnJDVVI3cWVaZ VptRnkzZ1c3ck9JaWZjWkxHNEg5TE1ybzlFYklSOGVYMUw=

Naicker, S. et al. (2020). The Novel Coronavirus 2019 Epidemic and Kidneys. Kidney In- 
ternational, 97, 824-828. https://doi.org/10.1016/j.kint.2020.03.001 https://schlr.cnki.net/Detail/index/SJPD 04/SJPDAB4A7D7E2B3110991853C124331F0 $\underline{093}$

Peng, B. B., Zhai, X. Y., Dong, Y. Y., Peng, Y. F., \& Jiao, Y. B. (2020). Thinking on the Improvement of International Humanitarian Relief Legislation in Response to COVID-19. China Disaster Relief Medicine, 8, 618-621.

https://kns.cnki.net/kcms/detail/detail.aspx?dbcode=CJFD\&dbname=CJFDAUTO\&file name $=J Y Z H 202011006 \& v=$ MTQxODFYMUx1eFITN0RoMVQzcVRyV00xRnJDVVI3 cWVaZVptRnkzaFU3eklMelRSWnJHNEhOSE5ybzlGWW9SOGU=

Song, W. (2020). Shekou Maritime: Eliminate the Epidemic Alarm within 18 Hours to Ensure the Safe Entry and Exit of Cruise Ships. China Maritime, No. 2, 20. https://kns.cnki.net/kcms/detail/detail.aspx?dbcode=CJFD\&dbname=CJFDLAST2020 \&filename $=$ HSZG202002016\&v=MDQ5OTVFWW9SOGVYMUx1eFITN0RoMVQzcV RyV00xRnJDVVI3cWVaZVptRnkzaFVyN0JMVDdSYWJHNEhOSE1yWTk=

Wang, L. S., Huang, D. S., Duan, W. Y., \& Duan, C. F. (2017). Application of Risk Matrix Method in Risk Assessment of Public Emergencies. Disease Surveillance, 32, 948-952. https://kns.cnki.net/kcms/detail/detail.aspx?dbcode=CJFD\&dbname=CJFDLAST2018 \&filename $=J B J C 201712016 \& v=$ MDU4MzZZb1I4ZVgxTHV4WVM3RGgxVDNxVHJX TTFGckNVUjdxZVplWm1GeTNoVUx6S0x5L0JiYkc0SDliTnJZOUU=

Wang, R. P., Guo, X. Q., \& Bi, A. H. (2011). Risk Assessment and Analysis of Infectious Diseases in Shanghai World Expo 2010 in Songjiang District. Disease Surveillance, 26, 305-309.

https://kns.cnki.net/kcms/detail/detail.aspx?dbcode=CJFD\&dbname=CJFD2011\&filen ame=JBJC201104020\&v=MjQ2MzMzcVRyV00xRnJDVVI3cWVaZVptRnkzaFU3M1B MeS9CYmJHNEg5RE1xNDIIWklSOGVYMUx1eFITN0RoMVQ=

Wang, X. Q., Lin, Y., \& Li, Z. P. (2010). Discussion on Epidemic Prevention and Control of International Cruise Ship Infectious Diseases. Chinese Journal of Frontier Health and Quarantine, 33, 159-161.

https://kns.cnki.net/kcms/detail/detail.aspx?dbcode=CJFD\&dbname=CJFD2010\&filen

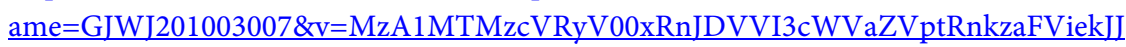
aWZjWkxHNEg5SE1ySTIGWTRSOGVYMUx1eFITNORoMVQ

Xia, J., Cai, L., Chen, L., Zhou, R., Pan, J. H., Wang, W. X., Zhu, P. Q., Meng, C. Y., \& Qin, J. (2019). Establishment of Risk Assessment System for International Cruise Infectious Diseases. Chinese Journal of Frontier Health and Quarantine, 42, 319-322+344. https://kns.cnki.net/kcms/detail/detail.aspx?dbcode=CJFD\&dbname=CJFDLAST2019 \&filename $=$ GJWJ201905005\&v=MjU5NThNMUZyQ1VSN3FlWmVSdUZ5 cmdWNzd PSWlmY1pMRzRIOWpNcW85RllZUjhlWDFMdXhZUzdEaDFUM3FUclc=

Xue, X. C., \& Yao, W. P. (2014). Study on the Application of Risk Assessment in the Prevention and Control of Infectious Diseases at Frontier Ports. Zhonghua Sanitary Insecticide, 20, 412-415.

https://kns.cnki.net/kcms/detail/detail.aspx?dbcode=CJFD\&dbname=CJFD2014\&filen ame=WSSC201405007\&v=MTc3NTQzaFU3dkpNajdZYmJHNEg5WE1xbzlGWTRSO GVYMUx1eFlTN0RoMVQzcVRyV00xRnJDVVI3cWVaZVptRnk=

Xue, Y. L. (2018). Building a “One Network, Four Warehouses and Three Platforms” to Build a Port Public Health Risk Monitoring and Early Warning Decision-Making System. Port Health Control, 23, 1-4.

https://kns.cnki.net/kcms/detail/detail.aspx?dbcode=CJFD\&dbname=CJFDLAST2018 \&filename $=$ KAWS201801001\&v=MTcxOTVUcldNMUZyQ1VSN3FIWmVabUZ5M2h VYi9KTG16Y2ZiRzRIOW5Ncm85RlpZUjhlWDFMdXhZUzdEaDFUM3E=

Yang, M. Z., Li, S. B., \& Tang, H. L. (2010). Review of Safety Risk Assessment Model. 
Journal of Henan Institute of Education (Natural Science Edition), 19, 6-8+13.

https://kns.cnki.net/kcms/detail/detail.aspx?dbcode=CJFD\&dbname=CJFD2010\&filen ame $=$ HLKB201004004\&v=MjAzMDZZUzdEaDFUM3FUcldNMUZyQ1VSN3FIWmV abUZ5M2hVTDdPTFNIQWJMRzRIOUhNcTQ5RllJUjhlWDFMdXg=

Yu, B., \& Li, X. D. (2013). Discussion on Epidemic Prevention and Control of International Cruise Ships at Tianjin Port. Port Health Control, 18, 35-39.

https://kns.cnki.net/kcms/detail/detail.aspx?dbcode $=$ CJFD\&dbname $=$ CJFD2013\&filen ame=KAWS201304016\&v=MTU3ODhIOUxNcTQ5RVlvUjhlWDFMdXhZUzdEaDFU M3FUcldNMUZyQ1VSN3FlWmVabUZ5M2hVYnJTGl6Y2ZiRzQ= 